\title{
Praktiese lesse in natuurwetenskap: 'n Gevallestudie
}

\begin{tabular}{|c|c|}
\hline \multicolumn{2}{|c|}{$\begin{array}{l}\text { Authors: } \\
\text { Sydney Mothokwa }{ }^{1} \\
\text { Estelle Gaigher }^{1} \\
\text { Elize Randall }^{1 \dagger} \\
\text { Melanie Moen }^{2}\end{array}$} \\
\hline \multicolumn{2}{|c|}{$\begin{array}{l}\text { Affiliations: } \\
\text { 'Department of Science } \\
\text { Mathematics Technolgy } \\
\text { Education, University of } \\
\text { Pretoria, South Africa }\end{array}$} \\
\hline \multicolumn{2}{|c|}{$\begin{array}{l}{ }^{2} \text { Department of Early } \\
\text { Childhood Education, } \\
\text { University of Pretoria, } \\
\text { South Africa }\end{array}$} \\
\hline \multicolumn{2}{|c|}{$\begin{array}{l}\text { Corresponding author: } \\
\text { Estelle Gaigher, } \\
\text { estelle.gaigher@up.ac.za }\end{array}$} \\
\hline \multicolumn{2}{|c|}{$\begin{array}{l}\text { Dates: } \\
\text { Received: } 04 \text { Dec. } 2015 \\
\text { Accepted: } 15 \text { July } 2016 \\
\text { Published: } 31 \text { Jan. } 2017\end{array}$} \\
\hline \multicolumn{2}{|c|}{$\begin{array}{l}\text { How to cite this article: } \\
\text { Mothokwa, S., Gaigher, E., } \\
\text { Randall, E. \& Moen, M., } \\
\text { 2017, 'Praktiese lesse in } \\
\text { natuurwetenskap: 'n } \\
\text { Gevallestudie', Suid-Afrikaanse } \\
\text { Tydskrif vir Natuurwetenskap } \\
\text { en Tegnologie 36(1), a1375. } \\
\text { https://doi.org/10.4102/satnt. } \\
\text { v36i1.1375 }\end{array}$} \\
\hline \multicolumn{2}{|l|}{$\uparrow, 1955-2013$} \\
\hline \multicolumn{2}{|c|}{$\begin{array}{l}\text { Copyright: } \\
\text { (C) 2017. The Authors } \\
\text { Licensee: AOSIS. This } \\
\text { is licensed under the } \\
\text { Creative Commons } \\
\text { Attribution License. }\end{array}$} \\
\hline \multicolumn{2}{|l|}{ Read online: } \\
\hline 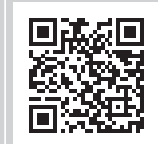 & $\begin{array}{l}\text { Scan this QR } \\
\text { code with your } \\
\text { smart phone or } \\
\text { mobile device } \\
\text { to read online. }\end{array}$ \\
\hline
\end{tabular}

Hierdie artikel beskryf ' $n$ gevallestudie wat bydra tot die navorsingsliteratuur oor die ontwikkeling van 21ste-eeuse vaardighede in wetenskapklasse in Suid-Afrika. Die studie ondersoek die wyse waarop vier ervare natuurwetenskaponderwysers praktiese lesse in hulle Graad 7-klasse in die Limpopo-provinsie integreer. Data is deur middel van dokumentontleding, leswaarneming en semigestruktureerde onderhoude ingesamel. Die studie is gebaseer op 'n teorie van kurrikulumimplementering vir wetenskaponderrrig in ontwikkelende lande. Die resultate word ten opsigte van voorbereiding, aanbieding en assessering van praktiese lesse bespreek. Die studie het aan die lig gebring dat hierdie onderwysers praktiese lesse op 'n tradisionele manier aanbied, eerder as om 21ste-eeuse benaderings te volg. In die meeste gevalle ontbreek noodsaaklike besonderhede tydens lesvoorbereidings, terwyl die leerders passiewe waarnemers is en die assessering op kennis eerder as vaardighede fokus. Verder is die volgende probleemareas geïdentifiseer: die onvoldoende toekenning van tyd vir die onderrig van natuurwetenskappe, asook 'n gebrek aan toepaslike hulpbronne. Die insig waartoe in die studie gekom is, kan gebruik word om die implementering van die kurrikulum te verbeter en om leiding aan die onderwysers te bied ten opsigte van die integrasie van praktiese lesse in natuurwetenskap.

Practical lessons in natural science: A case study. This article reports a case study that contributes to the literature on the development of 21st century skills in science classrooms in South Africa. The study explores the manner in which four experienced natural science teachers integrate practical lessons into their Grade 7 classes in the Limpopo province. The study is based on a theory of curriculum implementation for science education in developing countries. Data was collected through document analysis, lesson observations and semistructured interviews. The results are discussed in terms of the preparation, enactment and assessment of practical lessons. The study revealed that these teachers presented practical tasks in a traditional manner, rather than using 21st century approaches. Typically, lesson preparation lacked essential detail, while learners were passive observers, and assessment focused on knowledge rather than skills. Additionally, inadequate time allocation for the teaching of natural science, coupled with a lack of appropriate resources, were identified as areas of concern. The insight gained in this study should be used to improve curriculum implementation and to guide teachers regarding practical lesson integration in their classrooms.

\section{Inleiding}

Die benutting van wetenskap en tegnologie in die 21ste eeu is afhanklik van vaardigheidsontwikkeling in skole (Departement van Onderwys [DvO] 2002; Millar 2006). Wetenskaponderwysers moet streef om hulle leerders te help om vaardighede, eerder as bloot net inhoudkennis, te verwerf sodat leerders in staat is om nuwe probleme wat deur die nuwe wêreld gegenereer word, op te los. Die ontwikkeling van vaardighede is ' $n$ probleem wat inderwaarheid wêreldwyd voorkom (Barber et al. 2011; Clough \& Olson 2008).

Met die bekendstelling van Kurrikulum 2005 (K2005) in 1998, het die Suid-Afrikaanse regering hulle aandag op vaardigheidsontwikkeling gevestig en weg beweeg van tradisionele praktyke wat op die bemeestering van inhoudskennis gegrond was (Hattingh, Aldous \& Rogan 2007; Maree et al. 2006). Hierdie benadering is in ooreenstemmimg met wêreldwye hervorming om ondersoekende leer in wetenskaponderrig te bevorder (Millar 2006). Die algehele bedoeling van K2005 was om 'n konkrete wetenskaplike grondslag te vestig ten einde wetenskaplik geletterde landsburgers te ontwikkel wat in staat sal wees om op nasionale sowel as internasionale vlak (DvO 2002; Kotze 2008) te kan meeding en wat ook tot die ekonomiese ontwikkeling van die land sal kan bydra (Bantwini 2010). K2005 het egter nie die gewenste resultate gelewer nie en 
is opgevolg deur verskeie hersienings, waarvan die Kurrikulum- en Assesseringsbeleidsverklaring (KABV) die jongste is (Departement van Basiese Onderwys [DvBO] 2011).

Die Suid-Afrikaanse KABV-dokument is op drie spesifieke doelwitte vir wetenskap gegrond, naamlik om wetenskap te kan beoefen, om die vakinhoud te ken en te verstaan en derdens, om die gebruike van wetenskap te verstaan (DvBO 2011). Om wetenskap te kan beoefen, word verduidelik as: "Leerders moet in staat wees om ondersoeke te voltooi, probleme te analiseer en praktiese prosesse en vaardighede te gebruik in die evaluering van oplossings"(DvBO 2011:10), wat voortbou op die uitkomste wat vir K2005 in die vooruitsig gestel is. Die implementering van hervormde kurrikula is egter problematies, nie net in SuidAfrika nie, maar ook wêrelwyd (Millar 2004; Rogan \& Aldous 2005; Van der Valk \& De Jong 2009). Rogan (2004) het bevind dat praktiese lesse feitlik identies is aan lesse wat gedurende die dae voor K2005 aangebied is. Ondanks grootskaalse professionele ontwikkeling vir wetenskaponderwysers (Bantwini 2010) het onlangse studies aangedui dat ondersoekende leer selde geïmplementeer word (Maila 2013; Van der Schyff 2015). Die probleem word vererger in veral landelike gebiede waar tradisionele transmissiemetodes die klaskamerpraktyk oorheers (Maree et al. 2006).

Daar is ' $n$ duidelike behoefte om te verstaan hoe onderwysers ondersteun kan word om steeds vaardigheidsontwikkeling in die klaskamer te onderrig, te midde van uitdagings soos 'n tekort aan hulpmiddels en onvoldoende opleiding. Die situasie in klaskamers moet egter eers indringend begryp word voordat werkbare oplossings gevind kan word. Hierdie studie poog om by te dra tot die navorsingsliteratuur om diep insig te verkry in die wyse waarop onderwysers praktiese lesse in wetenskaponderrig gebruik. Die volgende navorsingsvraag is gestel: Hoe integreer onderwysers praktiese lesse by die onderrig van natuurwetenskappe in Graad 7-klasse? Hierdie vraag is aan die hand van die volgende drie subvrae ondersoek:

- Hoe beplan onderwysers praktiese lesse vir Graad 7-klasse?

- Hoe bied onderwysers praktiese lesse in Graad 7-klasse aan?

- Hoe assesseer onderwysers praktiese vaardighede in Graad 7-klasse?

'n Gevallestudie is onderneem om grondige insig in die situasie te kry. Hierdie soort insig kan beleid beïnvloed en geskikte professionele ondersteuning aan onderwysers moontlik maak.

\section{Literatuuroorsig}

Die literatuur word bespreek met betrekking tot die beplanning, aanbieding en assessering van praktiese werk om ' $n$ agtergrond aan die drie subnavorsingsvrae te bied.

\section{Beplanning van praktiese lesse}

Om vaardighede op 'n suksesvolle manier te onderrig, moet praktiese lesse deeglik beplan word, die aanbiedings moet georganiseer word en gesonde besluite oor optrede moet geneem word, terwyl die hulpbronne voor aanvang van die les aangepas moet word waar nodig (Rodrigues et al. 2010). 'n Goed ontwerpte praktiese les behels veel meer as bloot die keuse van ' $n$ taak uit ' $n$ bestaande bron. Dit sluit ook al die nodige aspekte in, soos die tema, duidelik omskrewe doelwitte, hulpbronne, toepaslike strategieë en metodes, asook die tyd wat geskeduleer word om die aktiwiteit af te handel (Barber et al. 2011).

Tensy praktiese lesse ontwerp word met 'n spesifieke en uitdagende mikpunt in gedagte, is dit moeilik om vaardighede te ontwikkel (Millar 2004). Internasionale literatuur dui daarop dat sommige onderwysers hulle lesse swak beplan (Akerson \& Hanuscin 2007). In Suid-Afrika is bevind dat party onderwysers geen lesvoorbereiding doen nie (Bantwini 2009).

\section{Aanbieding van praktiese lesse}

Leerders ontwikkel wetenskaplike vaardighede baie makliker wanneer hulle by 'n aktiwiteit betrek word (Frost 2010). Olitsky (2007) voer ook aan dat indien die leerders nie die kans gebied word om aan die praktiese werkproses deel te neem nie, hulle nie met die wetenskap identifiseer nie. Dit is die onderwyser se verantwoordelikheid om riglyne te gee en die leerders te wys hoe om toerusting te hanteer, data te interpreteer en gevolgtrekkings, gebaseer op die aktiwiteite wat gedoen is, te maak (Millar 2004).

Die bevindings van die projek van die Mpumalanga Secondary Science Initiative (MSSI), toon aan dat die leerders slegs aan die onderwysers se demonstrasies tydens praktiese opdragte blootgestel is (Rogan \& Aldous 2005). Verder dui die literatuur daarop dat baie Suid-Afrikaanse wetenskapklaskamers, veral in die landelike gebiede, gekenmerk word deur konserwatiewe onderrigmetodes (Maree et al. 2006) Hierdie tipe praktyk dui op 'n swak ooreenstemming tussen die beoogde en die geïmplementeerde kurrikulum (Lelliot et al. 2009). Suid-Afrika is egter nie die enigste land wat hierdie soort probleem ervaar nie. In Nederland is ook bevind dat die onderwysers soms 'n resepmatige benadering tydens praktiese lesse volg (Van der Valk \& De Jong 2009). 'n Benadering soos dié laat die leerders gewoonlik toe om praktiese opdragte uit te voer, soms sonder dat hulle dit verstaan of die kans gebruik om na te dink oor die doel van die les.

\section{Assessering}

Die hoofdoel van die assessering van praktiese opdragte is om te verseker dat die leerders wetenskaplike vaardighede kan demonstreer (Clough \& Olson 2008). Die assessering van vaardighede behels fisieke sowel as kognitiewe aktiwiteite, en daarom is skriftelike assessering onvoldoende. Uit die literatuur blyk dit dat die ontwikkeling van vaardighede beter geassesseer word wanneer die leerders waargeneem word terwyl hulle praktiese opdragte uitvoer (Le Grange 2008). Dit is dus belangrik dat wetenskaponderwysers geldige en betroubare leerdergesentreerde, praktiese assesseringsinstrumente moet ontwikkel (DvO 2007; Matthews \& McKenna 2005). Volgens Kotze (2008) is die beste manier om praktiese opdragte te assesseer die gebruik van 'n rubriek of 'n kontrolelys. Skriftelike assessering van praktiese werk word gekritiseer omdat 
dit beperkte toepaslikheid op noodsaaklike wetenskaplike vaardighede en bevoegdhede toon (Ramnarain 2014).

In Suid-Afrika dui die literatuur daarop dat daar steeds natuurwetenskaponderwysers is wat hoofsaaklik op toetse en eksamens fokus (Le Grange 2008). Sahin (2009) voer aan dat vaardighede van die 21ste eeu gemeet moet word deur assesseringstrategieë van die 21ste eeu. Dit blyk ook uit die literatuur dat assessering van praktiese opdragte gepaard moet gaan met onmiddelike, billike en konstruktiewe en/of opbouende kommentaar, en nie net numeriese aanduiers nie (Clymer \& William 2007).

\section{Teoretiese raamwerk}

Hierdie studie maak gebruik van die Teorie van Kurrikulumimplementering vir Wetenskaponderrig in Ontwikkelende Lande (Rogan \& Grayson 2003) as teoretiese vertrekpunt. Die teorie bestaan uit drie hoofkonstrukte, naamlik die Profiel van Implementering, Kapasiteit om te Innoveer en Invloede van Buite. Die raamwerk sluit vlakomskrywers vir elke konstruk in, waarvolgens elke konstruk op 'n skaal van een tot vier beoordeel word. Hierdie teorie is in verskillende studies gebruik om die omvang van die implementering van die wetenskapkurrikulum in SuidAfrika te ondersoek (bv. Hattingh et al. 2007, Lelliot et al. 2009).

Die huidige studie fokus op die konstruk van die Profiel van Implementering, om die integrering van praktiese lesse in die onderrig van natuurwetenskap te ondersoek. Die mate van kompleksiteit van praktiese wetenskapslesse word deur Rogan en Grayson (2003) op vier vlakke beskryf. Volgens die vlakomskrywers behels vlak een onderwysergesentreerde demonstrasies, vlak twee behels ' $n$ mate van leerderdeelname aan demonstrasies en resepmatige praktiese werk, vlak drie behelsbegeleideontdekking, terwylvlakvierleerdergesentreerde ondersoeke met oop uitkomste in die vooruitsig stel (Rogan \& Grayson 2003). Vlakke drie en vier van die raamwerk stem goed ooreen met die uitkomste wat deur die KABV in die vooruitsig gestel word.

\section{Metodologie}

'n Vertolkende paradigma en 'n kwalitatiewe benadering met ' $n$ gevallestudie as navorsingsontwerp is gebruik om insig in die navorsingsprobleem te verkry (Leedy \& Ormrod 2013). Die navorsers het die ondersoek op 'n onpartydige manier aangepak ten einde ' $n$ betroubare geheelbeeld daar te stel wat op die data gebaseer is (Creswell 2008). Doelbewuste steekproefneming is gebruik om die skole en deelnemers te kies (McMillan \& Schumacher 2006). Die geografiese ligging het besondere aandag geniet om te verseker dat ' $n$ landelike bevolking ingesluit is. Gevolglik is die Limpopo-provinsie en skole met diverse omgewings en ekonomiese omstandighede gekies. Sewe skole is aanvanklik gekies, maar twee skole het onttrek en 'n onderwyser het siek geword, wat beteken dat die finale steekproef uit vier skole bestaan het.

Die data-insamelingsmetode het dokumentontleding, leswaarneming en semigestruktureerde onderhoude ingesluit. Die beplanningsdokumente van elke onderwyser is ontleed, ' $n$ onderhoud van ongeveer ' $n$ uur is gevoer en twee aanbiedings van praktiese lesse is waargeneem. Direkte waarnemings is vanuit 'n onopvallende posisie gemaak om eerstehandse inligting in 'n natuurlike omgewing in te samel (Leedy \& Ormrod 2013; Le Grange 2008). Die data is in terme van vooraf bepaalde kategorieë nl. lesvoorbereiding, lesaanbieding en assessering geïnterpreteer om die subnavorsingsvrae te beantwoord. Sodoende is vooroordeel gedurende datainterpretasie verminder.

\section{Bevindings en bespreking}

Die bespreking van resultate word voorafgegaan deur eers die agtergrond van die skole en onderwysers te gee. Hierna volg 'n uiteensetting van die bevindings in drie afdelings, volgens die drie subnavorsingsvrae. Ter afsluiting volg 'n bespreking van uitdagings rakende praktiese lesse, volgens die ervarings van die deelnemers aan hierdie studie.

\section{Biografiese inligting}

Die steekproef van skole wat in hierdie studie gebruik is, bestaan uit 'n diverse stedelike skool, 'n skool in 'n informele nedersetting, 'n skool in 'n landelike gebied, asook'n plaasskool. Die deelnemers was ervare onderwysers met tussen 11 en 28 jaaronderwyservaring. Aldiedeelnemershetonderwysdiplomas as eerste kwalifikasie, maar slegs onderwysers A en E het in wetenskap gespesialiseer. Hoewel almal later bykomende kwalifikasies verwerf het, was geen van hierdie bykomende kwalifikasies in wetenskaponderrig nie. Hoewel al die onderwysers gedurende hulle loopbane kort kursusse in wetenskap bygewoon het, het twee van hulle (onderwysers C en D) geen formele kwalifikasies in natuurwetenskaponderrig nie. Die inligting word in Tabel 1 opgesom.

TABEL 1: Biografiese inligting oor die onderwysers.

\begin{tabular}{|c|c|c|c|c|c|}
\hline Onderwyser & Tipe skool & Fasiliteite & Kwalifikasies & Onderwyservaring & Wetenskaponderrigervaring \\
\hline \multirow[t]{3}{*}{$\bar{A}$} & Landelik & Water & Onderwysdiploma (spesialiseer in wetenskap) & 11 jaar & 6 jaar \\
\hline & & Elektrisiteit & Gevorderde sertifikaat & & \\
\hline & & Min apparaat & B.Ed.-Hons & & \\
\hline c & Stedelik & Laboratorium \& apparaat & Onderwysdiploma (geen wetenskap nie) & 23 jaar & 23 jaar \\
\hline \multirow[t]{3}{*}{ D } & Township & Water & Onderwysdiploma & 28 jaar & Voorheen hoërskool-wetenskap \\
\hline & & Min apparaat & Verdere diploma & & \\
\hline & & - & Gevorderde sertifikaat (geen wetenskap nie) & & \\
\hline \multirow[t]{3}{*}{ E } & Plaas & Water & Onderwysdiploma (spesialiseer in wetenskap) & 20 jaar & 17 jaar (Gr. 4-6) \\
\hline & & Min apparaat & Gevorderde sertifikaat (voorligting) & & \\
\hline & & - & B.Ed.-Hons & & \\
\hline
\end{tabular}




\section{Voorbereiding van praktiese lesse}

'n Merkbare verskil is oor die algemeen waargeneem tussen die lesvoorbereiding van die onderwysers in hierdie studie en wat in die literatuur verwag word. 'n Goed ontwerpte praktiese les behels veel meer as 'n beskrywing van apparaat en metode; dit moet doelwitte, strategieë, stappe om leeruitkomste te bereik, asook assesseringstrategieë insluit (Barber et al. 2011).

Die onderwysers se beplanningslêers het template, werkkaarte en voorbereide lesse bevat. 'n Templaat verwys na 'n onvoltooide generiese beplanningsvorm met geskikte opskrifte vir onderwysers se lesbeplanning, terwyl 'n werkkaart verwys na 'n vorm wat vir 'n spesifieke les ontwerp is en deur leerlinge voltooi word om hulle praktiese resultate en gevolgtrekkings aan te teken. Onderwysers A, C en $\mathrm{E}$ het template vir lesvoorbereiding gebruik, terwyl onderwyser D 'n oefenboek gebruik het. Onderwyser A se lêer bevat 'n kopie van 'n templaat, wat uit 'n onderwysershulpbronpakket vir natuurwetenskap gekopieer is. Die vorms is egter onvoltooid vir die lesse wat waargeneem is. Die lêer bevat egter ook 'n volledige lesplan wat uit 'n handboek of ' $n$ ander bron gekopieer is en tydens een van sy lesse gebruik is. Hierdie plan het leerderaktiwiteit, hulpbronne en 'n werkkaart ingesluit. Onderwyser $C$ het lesplanne op die skool se beplanningstemplate voltooi. Die beplanning was buitengewoon in die sin dat dit ooreengestem het met die departementele tydskedule vir daardie week en het die tema, die vaardighede wat ontwikkel moet word, die rolle van die onderwysers en leerders, en die assesseringstrategieë ingesluit. Die lêer het ook verskillende werkkaarte bevat wat die leerders ná die praktiese lesse voltooi het. Onderwyser D se beplanning het op die inhoud gefokus en 'n lys van apparaat was die enigste aanduiding dat 'n praktiese aktiwiteit beplan word. Belangrike inligting soos datums, die duur van die les en die rolle van die onderwysers en leerders het ontbreek. Onderwyser E het template as voorbereiding vir sy lesse voltooi. Aspekte soos die tema, datum, duur en assesseringstandaarde was daarby ingesluit. In die ruimte vir onderwyser- en leerderaktiwiteite het hy inhoud ingevul wat hy beplan om te onderrig en wat die leerders reeds behoort te ken. Hoewel daar geen aanduiding van apparaat was nie, het een van die lesse wat vir waarneming aangebied is, wel demonstrasies sowel as leerderdeelname ingesluit.

Die meeste van die praktiese lesplanne het nie besonderhede bevat nie, hoewel hulle algemene aspekte soos die onderwerp, tema, datum, duur en assesseringstandaarde ingesluit het. Van die praktiese lesse het nie die doelwitte, vaardighede wat ontwikkel moet word en veiligheidskwessies aangedui nie. Die rolle van die onderwyser en die leerders, asook hulle interaksies, is ook nie aangetoon nie, wat strydig is met die klem wat op interaksies in die Profiel van Implementering geplaas word (Rogan \& Grayson 2003). Die gebrek aan besonderhede by die beplanning kan vererger word deur die gebruik van template, veral wanneer probeer word om praktiese lesse te ontwerp. Daar is oor die algemeen niks verkeerd met die gebruik van template nie; wat egter problematies word, is die manier waarop die onderwysers die template gebruik. Dokumentontleding het aan die lig gebring dat die template beperkte ruimte laat om besonderhede in te vul. Onderwysers verskaf dus beperkte besonderhede en laat belangrike inligting uit in hulle beplanning.

\section{Aanbieding van praktiese lesse}

Hoewel die literatuur aandui dat leerders se wetenskaplike vaardighede beter ontwikkel wanneer hulle by 'n prosedure betrek word (Frost 2010), het die leerders net tydens twee van die agt waargenome praktiese lesse die geleentheid gekry om die apparaat te manipuleer en dwarsdeur die proses aktief deel te neem. Een van hierdie lesse is by skool $C$ en die ander een by skool E waargeneem.

Onderwyser C het een goed georganiseerde praktiese les aangebied. Veiligheidsmaatreëls in die laboratoriums is wel getref en die leerders is in klein, beheerbare groepe verdeel om aan die aktiwiteite deel te neem. Die groepleiers moes die chemikalieë by die voorste tafel gaan haal voor die aktiwiteit plaasgevind het en dit weer na die tyd teruggeneem het. Al die leerders het ' $n$ geleentheid gekry om aan die aktiwiteite deel te neem deur die sure en basisse te meng, indikators by te voeg en waar te neem hoe die kleur verander. Hulle is ook toegelaat om onderling oor die uitkomste van die ondersoek te kommunikeer. Gedurende die aktiwiteit het onderwyser C gedemonstreer hoe om 'n spuitnaald te gebruik om die indikator by die oplossings te voeg. Hy het deurentyd van die een groep na die ander beweeg, leerders gehelp en vrae gestel. Die ander les wat onderwyser $C$ aangebied het, was 'n demonstrasie.

In sy eerste les wou onderwyser E energie-oordrag in verskillende situasies demonstreer. Hy het eers 'n battery en 'n gloeilamp gebruik, maar toe ontdek dat die battery pap was. Hy het egter voortgegaan om die konsep te verduidelik terwyl hy die apparaat in die lug gehou het. Daarna het hy die leerders betrek deur rekkies uit te deel waarmee hulle potensiële energie moes ondersoek. In die tweede les het onderwyser E die klas in groepe van agt leerders elk verdeel. Hullehet batterye, gloeilampe, motors en klein draadkarretjies van die huis af gebring en hulle in die klas gedemonstreer. Aan die einde van die les het die onderwyser ook probeer om die werking van 'n dinamo te demonstreer, maar omdat die gloeilamp stukkend was, was dit onsuksesvol. Een van die leerders het egter 'n gloeilamp verskaf wat hy van die huis af gebring het, waarna die onderwyser dit gekonnekteer het en die opwekking van elektriese energie kon demonstreer. Dit was duidelik dat onderwyser E nie die apparaat voor die praktiese lesse getoets het nie.

Die oorblywende praktiese lesse was hoofsaaklik onderwyserdemonstrasies, terwyl die leerders die prosedures waargeneem en die onderwysers se mondelinge vrae beantwoord het. Albei lesse wat onderwyser D aangebied het, was demonstrasies. Die een het oor die skeiding van 
mengsels en die ander oor faktore wat die spoed van oplossing beïnvloed, gehandel. Onderwyser A het twee demonstrasielesse gegee. Die een het oor die oordrag van hitte gegaan waarvoor hy 'n beker met water, 'n spiritusbrander en lepels wat van verskillende materiaal gemaak is, gebruik het. Hy het die lepels in die kokende water geplaas en die leerders genooi om aan die lepels te vat om vas te stel hoe goed hulle hitte gelei. Die ander les het oor energie-oordrag gehandel waar die onderwyser sy motor wat naby aan die klaskamer geparkeer was, gebruik het. Hoewel hulle nie aktief betrokke was nie, het die leerders die geleentheid gekry om die battery van die motor te identifiseer, en waar te neem hoe chemiese energie in lig-, kinetiese, hitteen klankenergie verander toe die enjin aangeskakel is. In die ander gevalle waar onderwysers demonstrasies gedoen het, was die leerders slegs waarnemers en nie deelnemers nie.

Gedurende die onderhoude het 'n paar van die onderwysers genoem dat hulle soms verplig is om praktiese lesse as teorie aan te bied weens ' $n$ gebrek aan apparaat. Onderwyser E het soos volg vertel:

'If the apparatus are not there we just leave it. Because you will go around, if you need methane and methane is not here, you want to go to another school and you find that there is nothing there at the neighbouring schools you just leave it. And you teach theory.' [Indien daar nie apparaat is nie, los ons dit net. Omdat ons oral soek as ons metaan wil hê maar nêrens metaan kry nie, ook nie by 'n ander skool nie of enige van die naburige skole nie, los jy dit maar. En dan onderrig jy die teorie.] (Deelnemer E, manlik, onderwyser, 42 jaar [outeur se eie vertaling.])

Die leswaarnemings, asook die onderhoude, het aan die lig gebring dat die onderwysers dikwels praktiese lesse vervang met verduidelikings van die verloop van eksperimente sonder om enige apparaat te gebruik.

\section{Assessering van praktiese vaardighede}

Daar was bewyse in die leerders se lêers dat onderwysers $C$ en E soms rubrieke gebruik om praktiese vaardighede te assesseer. Die assessering het egter oor die algemeen nie op praktiese vaardighede gefokus nie. Buiten die toetse wat deur die DvBO voorgeskryf word, is geen assesseringsinstrumente in die onderwysers se dokumentasie opgespoor nie. Gedurende die onderhoude het die onderwysers ook hoofsaaklik na die departementele toetse verwys hierdie toetse bevorder kennisverwerwing en maak voorsiening vir punte vir aanspreeklikheidsdoeleindes, maar is nie bedoel om praktiese vaardighede te assesseer nie. William (2006) redeneer egter dat assessering as ' $n$ brug tussen die onderrig- en leerproses moet dien, en daarom moet dit op so 'n wyse ontwerp word dat dit beter leer bevorder.

Die studie het verder ook getoon dat drie van die onderwysers kennis oor die implementering van 'n rubriek het, maar slegs onderwyser $\mathrm{E}$ het rubrieke by die assessering van praktiese opdragte gebruik:

'If a learner is able to handle particular equipment I allocate a score.' [As ' $n$ leerder in staat was om sekere toerusting te kan hanteer, het ek 'n punt toegeken]. (Deelnemer E, manlik, onderwyser, 42 jaar [outeur se eie vertaling.])
Onderwyser D het verduidelik dat hy slegs die leerders se werkboeke kontroleer en onderteken. Hy het ook genoem dat sy groot werklading as departementshoof hom nie met genoeg tyd laat om breedvoerige assessering te doen nie. Onderwyser A het erken dat hy nie weet wat 'n rubriek is nie, maar het aangedui dat hy die skriftelike werk na elke praktiese opdrag assesseer. Onderwyser $C$ het aangedui dat hy op ' $n$ informele, sowel as ' $n$ formele manier die leerders se vordering nagaan, en gesê:

'And if they get $80 \%$ or more then I feel good because I can see that I was teaching and that my teaching was good. So I am testing a lot, but not always for the marks.' [En as hulle 80\% of meer kry, laat dit my goed voel omdat ek kan sien dat ek hulle iets geleer het en dat my onderrig goed was. Ek toets hulle dus gereeld, maar nie altyd vir punte nie.] (Deelnemer C, manlik, onderwyser, 45 jaar [outeur se eie vertaling.])

Hy het ook verduidelik dat hy die leerders soms 'n kaartspeletjie laat speel waar hulle woorde bymekaar moet pas, waarvoor hulle informele punte kry:

'This is a kind of test I give the learners. If they can match all the cards with the words, then my lesson was successful.' [Dit is 'n soort toets wat ek aan die leerders gee. As hulle al die kaarte by die woorde kan pas, was my les suksesvol.] (Deelnemer C, manlik, onderwyser, 45 jaar [outeur se eie vertaling.])

Laastens het die onderwysers wat aan die studie deelgeneem het, aangetoon dat assesseringsinstrumente selde deur hulle departementshoofde gemodereer word.

\section{Uitdagings}

Die grootste uitdaging vir die onderwysers by drie van die skole was die gebrek aan hulpbronne om praktiese lesse aan te bied. Hierdie onderwysers het aangedui dat hulle soms hulle eie geld gebruik om materiaal en apparaat aan te koop. Hieroor het onderwyser A die volgende gesê:

'It is a matter of consultation with the management ... The other thing you find that you end up using your money and in order to be refunded, hey, it is a process also. This is how we suffer when we do these things.' [Dit is 'n kwessie van konsultasie met die bestuur ... Die ander ding is dat jy op die ou end jou eie geld gebruik en om jou geld weer terug te eis, is omtrent ' $n$ proses. Dit is hoe swaar ons kry as ons hierdie dinge wil doen.] (Deelnemer A, Manlik, Onderwyser, 33 jaar [outeur se eie vertaling.])

Tog het sommige van die onderwysers die inisiatief geneem om alternatiewe materiaal te vind. Onderwyser D sien die gebrek aan apparaat nie as 'n ernstige probleem nie en verduidelik dit so:

'Not 100 per cent. Science is a practical subject. We have got a lot of tins that have been used up. You can use them as containers. We have glasses that we use to drink water. Although they are not marked, you can use them as beakers. So, lacking apparatus is not a major problem. Torches we do have. Energy transfer, stoves we light at homes, globes we use, heat energy, light energy. So, not having an apparatus, I do not think is a problem in presenting science.' [Nie 100 persent nie. Wetenskap is 'n praktiese vak. Ons het baie leë blikkies. Ons kan hulle as houers inspan. Ons het glase waaruit ons water drink. Hoewel hulle nie gemerk is nie, kan ons hulle as bekers gebruik. 
'n Gebrek aan apparaat is dus nie 'n groot probleem nie. Flitse, ons het hulle. Energie-oordrag, ons steek stofies tuis aan, ons gebruik gloeilampe, hitte-energie, ligenergie. Ek dink om nie apparaat te hê nie, is nie 'n probleem wanneer wetenskap aangebied word nie.] (Deelnemer D, manlik, onderwyser, 50 jaar [outeur se eie vertaling.])

Onderwyser D het ook aangedui dat daar skole is wat wel apparaat het, maar dat dit in onbruik is:

'But when I went to the neighbouring schools to go and ask, some of them even though they have got apparatus that are locked in steel cabinets doing nothing, they find it reluctant to offer me.' [Maar toe ek na die naburige skole gaan en navraag doen, was van die skole wat apparaat in staalkabinette toegesluit hou en nooit gebruik nie, hulle was teensinnig om dit vir my te leen.] (Deelnemer D, manlik, onderwyser, 50 jaar [outeur se eie vertaling.])

'n Verdere kwessie is dat die hulpbronne, in die besonder apparaat, mense en laboratoriums, onderling verwant is. Die beskikbaarheid van gesofistikeerde apparaat sonder 'n geskikte ruimte daarvoor en 'n kundige onderwyser om dit te gebruik, is nog 'n uitdaging in die integrering van praktiese lesse.

'n Gebrek aan genoeg tyd vir praktiese werk was nog 'n struikelblok vir die ontwikkeling van wetenskaplike vaardighede by leerders, soos ook bevind deur Barber et al. (2011). Alhoewel beleidsmakers die hoeveelheid tyd vir die onderrig van natuurwetenskap bepaal (DvBO 2011), besluit die skoolbestuur oor die tydsduur van periodes (Rogan \& Grayson 2003). Die meeste van die lesse is beplan vir 'n maksimum van 30 minute. Die werklike duur van die lesse was egter altyd korter. Hoewel van die onderwysers die voorbereidende besprekings die vorige dag afgehandel het, is dit op die een of ander manier deur te min tyd beïnvloed. 'n Voorbeeld is dat die leerders in skool C na en van die laboratorium moes stap, waardeur die beskikbare tyd verkort is. In een geval is 'n les kortgeknip vanweë die saalopening wat langer as gewoonlik geduur het. Gevolglik moes van die aktiwiteite onder druk voltooi word, wat die geleentheid om vaardighede aan te leer, ingeperk het.

\section{Slot}

Nieteenstaande onvoldoende opleiding en 'n tekort aan apparaat, openbaar die onderwysers gewilligheid en kreatiwiteit om praktiese lesse aan te bied. Onderwyser A het sy motorenjin op kreatiewe wyse ingespan om energie-oordrag te demonstreer. Onderwyser C, wat geen formele wetenskapopleiding het nie, het ' $n$ praktiese les georganiseer waartydens leerlinge self met sure en basisse kon eksperimenteer.

Die lesse het egter oor die algemeen nie voldoen aan die vereistes wat in die hervormingsliteratuur en die KABV gestel word nie. Slegs eenvoudige prosesvaardighede soos waarneming en die uitvoer van prosedures was inderdaad betrokke, maar ondersoekende vaardighede is nie ingeoefen nie. Volgens die Profiel van Implementering vertoon hierdie praktiese lesse meesal vlakeen-kenmerke, soos demonstrasies om die ontwikkeling van konsepte te ondersteun. In uitsonderlike gevalle is vlaktwee-kenmerke betrek waar demonstrasies 'n beperkte vorm van ondersoek bevorder het en aktiwiteite uitgevoer is waar die leerders geslote ondersoeke of resepmatige praktiese werk gedoen het. Die lesse het nie verskil van lesse wat voor K2005 in die onderrigstelsel aangebied is nie, wat soortgelyk is aan 'n bevinding wat 'n dekade gelede gemaak is (Hattingh et al. 2007; Maree et al. 2006; Onwu \& Stoffels 2005; Rogan 2004), waar demonstrasies die praktiese lesse oorheers het.

Die studie het ook getoon dat drie van die vier deelnemers praktiese lesse sonder voldoende voorbereiding aangebied het. Hoewel die onderwysers almal die een of ander vorm van voorbereiding gedoen het, het dit hoofsaaklik op inhoud gefokus sonder dat die besonderhede van die aktiwiteite en apparaat gespesifiseer is. Hierdie praktiese lesse was dus swak georganiseer en soms is disfunksionele apparaat aangebied. Die assessering wat deur die meeste onderwysers in dié studie gebruik is, het nie vaardigheidsontwikkeling by leerders aangemoedig nie. Die klem was op summatiewe assessering, soos deur die DvBO voorgeskryf, waarvolgens inhoudskennis getoets word, terwyl vaardighede agterweë bly. Die gevolgtrekking word dus gemaak dat dié onderwysers swak begrip het van die doel van beplanning en die assessering van praktiese lesse, wat die voordele van praktiese lesse belemmer. Bykomend hiertoe het onvoldoende tyd, asook 'n gebrek aan hulpbronne, die omvang van praktiese lesse ingeperk.

Hoewel hierdie bevindings nie veralgemeen moet word nie, is dit duidelik dat praktiese lesse oor die algemeen nie doeltreffend in die aanbieding van natuurwetenskap geïntegreer word nie. Leerders word nie die geleentheid gebied om hoë vlakke van vaardighede te ontwikkel nie. Die swak ooreenstemming tussen beleid en praktyk, wat 'n dekade gelede reeds deur Onwu en Stoffels (2005) waargeneem is, bestaan dus steeds in natuurwetenskap in sommige klaskamers. Ons beveel dus aan dat verdere ondersoek ingestel word oor hoe integrering van praktiese lesse in klaskamers ondersteun en gemoniteer kan word, asook na die onderwysers se oortuigings en houdings teenoor praktiese werk. Hierdie tipe navorsing kan bydra tot beter begrip van realiteite rakende die ontwikkeling van wetenskaplike vaardighede by leerders en wat gedoen kan word om die situasie in Suid-Afrika te verbeter.

\section{Erkenning Mededingende belange}

Die outeurs verklaar dat hulle geen finansiële of persoonlike verbintenis met enige party wat hom nadelig of voordelig kon beïnvloed het in die skryf van hierdie artikel nie.

\section{Outeursbydrae}

Hierdie artikel is gebaseer op 'n M.Ed.-studie deur S.M., onder leiding van E.R. en E.G. Die artikel is geskryf deur S.M. in samewerking met E.G. en M.M. 


\section{Literatuurverwysings}

Akerson, V.L. \& Hanuscin, D. L., 2007, 'Teaching nature of science through inquiry: Results of a 3-year professional development program', Journal of Research in Science Teaching 44(5), 653-680. http://dx.doi.org/10.1002/tea.20159

Bantwini, B.D., 2009, 'District professional development models as a way to introduce primary-school teachers in one district in South Africa', Journal of Education for Teaching: International Research and Pedagogy 35(2),169-182. http://dx.doi. org/10.1080/02607470902771094

Bantwini, B.D., 2010, 'How teachers perceive the new curriculum reform: Lessons from a school district in the Eastern Cape Province', International Journal of Educational Development 30, 83-90. http://dx.doi.org/10.1016/j.ijedudev.2009. 06.002

Barber, P., Chapman, G., Ellis-Sackey, C., Grainger, B. \& Jones, S., 2011, 'The ASE improving practical work in triple science learning skills network', Improving Practical Work in Science 92(340), 27-32.

Clough, M.P \& Olson, J., 2008, 'Teaching and assessing the nature of science: An introduction', Science and Education 17, 143-145. http://dx.doi.org/10.1007/ s11191-007-9083-9

Clymer, J.B. \& William, D., 2007, 'Improving the way we grade science', Educational Leadership 64, 36-42.

Creswell, J.W., 2008, Educational research: Planning, conducting and evaluating quantitative and qualitative research, 3rd ed., Merrill Prentice Hall, Upper Saddle River, NJ.

Departement van Basiese Onderwys, 2011, Kurrikulum-en Assesseringsbeleidsverklaring, Staatsdrukkery, Pretoria.

Departement van Onderwys, 2002, Hersiene Nasionale Kurrikulumverklaring Graad $R-9$ (Skole), Staatsdrukkery, Pretoria.

Departement van Onderwys, 2007, Nasionale Kurrikulumverklaring: Nasionale Beleid oor Assessering en Kwalifikasies vir skole in die Algemene Onderwys- en Opleidingsafdeling, Staatsdrukkery, Pretoria.

Frost, J., 2010, Learning to teach science in the secondary school: A comparison to school experience, 3rd ed., Routledge, London.

Hattingh, A., Aldous, C. \& Rogan, J.M., 2007, 'Some factors influencing the quality of practical work in science classrooms', African Journal of Research in Mathematics, Science and Technology Education 11(1), 75-90.

Kotze, G.S., 2008, 'Outcomes-based assessment strategies', in J.G. Maree \& W.J. Frase (eds.), Outcomes-based assessment: Facilitating best practice in classrooms, $2 \mathrm{nd}$ ed., pp.63-84 Heinemann Publishers, Sandton, South Africa.

Leedy, P.D. \& Ormrod, J.E., 2013, Practical research: Planning and design, 10th ed. Pearson, Boston.

Le Grange, L., 2008, 'Assessing competence in science and technology', in J.G. Maree \& W.J. Fraser (eds.), Outcomes-based assessment: Facilitating best practice in classrooms, 2nd ed., pp. 163-178, Heinemann Publishers, Sandton, South Africa.

Lelliot, A., Mwakapanda, W., Doidge, M., Du Plessis, J., Mhlolo, M., Msimanga, A. \& Bowie, L., 2009, 'Issues of teaching and learning in South Africa: A distinction between curriculum policy and implementation', African Journal of Research in Mathematics, Science and Technology Education, Special Issues, 47-64.
Maila, M. J. 2013, 'How educators interpret and integrate the assessment standards when conducting scientific investigations in the Intermediate Phase', unpublished M.Ed. dissertation, University of Pretoria, Pretoria.

Maree, K., Aldous, C., Hattingh, A., Swanepoel, A. \& Van der Linde M., 2006, 'Predictors of learner performance in Mathematics and Science according to a large-scale study in Mpumalanga', South African Journal of Education 26(2), 229-252.

Matthews, P.S.C. \& McKenna, P.J., 2005, 'Assessment of practical work in Ireland: A critique', International Journal of Science Education 27(10), 1211-1224. http:// dx.doi.org/10.1080/09500690500102573

McMillan, J.H. \& Schumacher, S., 2006, Evidence-based inquiry. Research in Education, 6th ed., Pearson, Boston, MA.

Millar, R., 2006, 'Twenty first century science: Insights from the design and implementation of a scientific literacy approach in school science', International Journal of Science Education, 28, 1499-1521. http://dx.doi.org/10.1080/09500690600718344

Millar, R., 2004, The role of practical work in the teaching and learning of science, National Academy of Sciences, Washington, DC.

Olitsky, S., 2007, 'Promoting student engagement in science: Interaction rituals and the pursuit of a community of practice', Journal of Research in Science Teaching 44(1), 33-56. http://dx.doi.org/10.1002/tea.20128

Onwu, G.O.M. \& Stoffels, N.T., 2005, 'Instructional functions in large, under-resourced science classes: Perspectives of South African teachers', Perspectives in Education 23(3), 79-91.

Ramnarain, U., 2014, 'Questioning the validity of inquiry assessment in a high stakes Physical Sciences examination', Perspectives in Education 32(1), 179-199.

Rodrigues, A.M., Tavares, L.B., Ortega, J.L. \& De Mattos, C.R., 2010, 'Planning lessons: A socio-historical-cultural approach in physics teaching', Science Education International 21(4), 241-251.

Rogan, J.M., 2004, 'Out of the frying pan ...?: Case studies of the implementation of Curriculum 2005 in some science classrooms', African Journal of Research in Mathematics, Science and Technology Education 8(2), 165-179. http://dx.doi. org/10.1002/tea.20054

Rogan, J.M. \& Aldous, C., 2005, 'Relationships between the constructs of a theory of curriculum implementation', Journal of Research in Science Teaching 42(3), 313-336.

Rogan, J.M. \& Grayson, D.J., 2003, 'Towards a theory of curriculum implementation with particular reference to science education in developing countries', with particular reference to science education in developing countries', org/10.1080/09500690210145819

Sahin, M.C., 2009, 'Instructional design principles for 21st century learning skills' World Conference on Educational Sciences 2009, Science Direct, Procedia Socia and Behavioural Sciences 2009(1), 1464-1468. http://dx.doi.org/10.1016/j. and Behavioural Scie

Van der Schyff, A., 2015, 'Die beoefening van praktykgebaseerde navorsing ter verbetering van die leerfasiliteringrol van Intermediêre Fase wetenskaponderwysers', ongepubliseerde M.Ed.-verhandeling. Universiteit van Pretoria, Pretoria.

Van der Valk, T. \& De Jong, O., 2009, 'Scaffolding science teachers in open-inquiry teaching' International Journal of Science Education 31(6), 829-850. http://dx. doi.org/10.1080/09500690802287155

William, D., 2006, Assessment for learning: Why, what and how?, Institution of Education, University of London, London. 